\title{
Dissolved organic nutrients $(C, N, P)$ in seawater on the continental shelf in the Southwestern South Atlantic with emphasis State Marine Park of Laje de Santos (SMPLS) - São Paulo - Brazil*
}

\author{
Elisabete de Santis Braga**, Gláucia Bueno Benedetti Berbel, Vitor Gonsalez Chiozzini, \\ Natalia Cristina Garrido Andrade
}

\begin{abstract}
Laboratory of Biogeochemistry of Nutrients, Micronutrients and Traces in Oceans - Instituto Oceanográfico - Universidade de São Paulo (Praça do Oceanográfico,191 - Butantã - São Paulo- SP- 05508120 - Brazil)

** Corresponding author: edsbraga@usp.br
\end{abstract}

\begin{abstract}
The main objective of this work is evaluate seasonal and spatial distribution of dissolved organic carbon (DOC), dissolved organic nitrogen (DON), dissolved organic phosphorus (DOP) and urea in 10 stations of the State Marine Park of Laje de Santos (SMPLS). Stations 1 to 4 (nearest the continent) and the stations 5 to 10 (nearest the marine park) all of them were on the continental shelf. The results show that no statistic significant seasonal variations were found for the DOC and DOP nevertheless DOC and DON in summer period were lightly above the winter period showing the increase in biological activities and continental influence. On the other hand, DON showed high values in June (2014 - winter) to January 2015 , ranging from 12.51 to $32.76 \mu \mathrm{mol}$ $\mathrm{L}^{-1}$ according to the ANOVA method $(\mathrm{p}<0.01)$. Low values of DON in January 2014 (0.32 to 8.98 $\mu \mathrm{mol} \mathrm{L}-1)$ was observed in a summer unusually dry, while the highest values were observed in July 2014 $\left(27.50 \mu \mathrm{mol} \mathrm{L}^{-1}\right)$. Urea presented low values in SMPLS region and coastal areas reaching $4.00 \mu \mathrm{mol}$ $\mathrm{L}^{-1}$. Sometimes, the urea concentration can be associated with diving activity in the park. DOC, DON and urea showed differences between SMPLS stations (5-10) and coastal stations (1-4). DOC coastal stations reached $267 \mu \mathrm{mol} \mathrm{L}^{-1}$, while the SMPLS the maximum value was $100 \mu \mathrm{mol} \mathrm{L}^{-1}$. No significant spatial variation between coastal stations and park were observed for the DOP (ANOVA $p<0.01$ ).
\end{abstract}

\section{RESUMO}

O principal objetivo deste trabalho é avaliar distribuição sazonal e espacial do carbono orgânico dissolvido (COD), nitrogênio orgânico (NOD), fósforo orgânico dissolvido (POD) e ureia em 10 estações do Parque Estadual Marinho da Laje de Santos (PEMLS). As estações 1 a 4 (mais próximas do continente) e as estações de 5 a 10 (mais próximas do parque marinho), todas na plataforma continental. Os resultados mostram que não foram observadas variações sazonais estatisticamente significativas para o COD e POD, todavia, o COD e o NOD, no período de verão apresentaram um pequeno aumento mostrando o aumento da atividade biológica e a influencia continental. Por outro lado, o NOD apresentou valores elevados em junho (2014 - inverno) e janeiro de 2015 , variando de 12.51 a $32.76 \mu \mathrm{mol}$ $\mathrm{L}^{-1}$, segundo o método de análise ANOVA $(\mathrm{p}<0,01)$. Foram observados baixos valores de NOD em janeiro de $2014\left(0,32-8,98 \mu \mathrm{mol} \mathrm{L}^{-1}\right)$, em um verão anormalmente seco, enquanto que os valores mais elevados foram observados em julho de 2014 (27.50 $\left.\mu \mathrm{mol} \mathrm{L}{ }^{-1}\right)$. Ureia apresentou valores baixos na região do PEMLS e zonas costeiras atingindo 4,00 $\mu \mathrm{mol}$ $\mathrm{L}^{-1}$. Muitas vezes, a concentração de ureia pode estar associada com atividade de mergulho no parque. COD, NOD e ureia apresentaram valores ou diferenças entre as estações no PEMLS (5-10) e aquelas mais costeiras (1-4). O COD nas estações costeiras atingiu $267 \mu \mathrm{mol} \mathrm{L}^{-1}$, enquanto que no PEMLS, o va-

Received: September 13, 2016

Approved: November 5, 2017

* Reference article of the Project MAPELMS - Environmental Monitoring of the State Marine Park of Laje de Santos 
Considering that dissolved organic compounds can also be monitored by means of the evaluation of $\mathrm{C}$, $\mathrm{N}, \mathrm{P}$ in their organic fraction, it was concluded that in the studied region the impact of eutrophic waters under continental and anthropic influence is minimal and these parameters could be monitored to support monitoring in the region.

Descriptors: Dissolved Organic Compounds, Organic Nitrogen, Organic Phosphorus, Organic Carbon, Urea, Marine Park.

\section{INTRODUCTION}

The availability of dissolved nitrogen and phosphorus in the organic forms in surface seawater is remarkable in view of the metabolism of the system based on processes of primary production and food chain, the generation and regeneration of organic matter and the production of organic detritus. The degradation of the organic form of matter occur by oxidation process while it is sinking and also when it reaches the sediment. The inventory of dissolved $\mathrm{N}$ and $\mathrm{P}$ in the marine system includes both organic and inorganic forms of these elements and to do so, it is necessary to use the most adaptable methodologies to determine the total and the organic forms. The UV method for the determination of organic nitrogen and phosphorus is of easy and precise application in seawater samples based on the photo-oxidation process (ARMSTRONG et al., 1966).

\section{Nitrogen}

The distribution of nitrogen compounds in the marine environment is governed by biological, physical and chemical factors that interact in highly complex reactions (Fig. 1). The nitrogen cycle comprises the inorganic components, compounds derived from organic matter and their integration with biological processes. Nitrogen is a key element for the synthesis of living organic matter, mainly proteins and nucleic acids. Dissolved nitrogenous compounds are most commonly used in marine primary production in inorganic ionic form such as $\mathrm{N}$-ammonium, nitrate and nitrite. The assimilation of $\mathrm{N}$-ammonium in the marine environment to support primary production is encouraged by the low energy demand of absorption lor máximo foi de $100 \mu \mathrm{mol} \mathrm{L} \mathrm{L}^{-1}$. Nenhuma variação significativa foi observada quanto à distribuição espacial entre as estações costeiras e as do parque para o POD (ANOVA $p<0,01$ ). Considerando-se que os compostos orgânicos dissolvidos também podem ser monitorados por meio da avaliação de $\mathrm{C}, \mathrm{N}, \mathrm{P}$ em sua fração orgânica, chegou-se à conclusão que, na região estudada o impacto de águas eutrofizadas sob influência continental e antrópica é mínimo e esses parâmetros poderiam ser monitorados para subsidiar o monitoramento na região.

Descritores: Compostos Orgânicos Dissolvidos, Nitrogênio Orgânico, Fósforo Orgânico, Carbono Orgânico, Ureia, Parque Marinho.

and assimilation to form proteins and the mobility of $\mathrm{N}$ speciation in the $\mathrm{N}$ biogeochemical cycle depends heavily on the activity of microorganisms. The main sources of $\mathrm{N}$-ammonium for the marine environment are the decomposition of organic nitrogen by bacteria, the excretion of zooplankton and other animals and anoxic bacterial activity on nitrate. On the other hand, the oxidation of $\mathrm{N}$-ammonium in the biogeochemical cycle, also with the help of microorganism form nitrite and nitrate and the recently discovered process of anammox (ANaerobic AMMonium OXidation), that produces $\mathrm{N}$ gas (van $\mathrm{DE}$ VOSSENBERG, 2008). Other sources such as terrestrials discharge and rainfall over the sea introduce $\mathrm{N}$-ammonium into oceans. Yet, main sinks of $\mathrm{N}$-ammonium include the assimilation by phytoplankton and the oxidation to nitrite and nitrate by the process of nitrification (WADA; HATTORI, 1991). The nitrate-nitrogen nutrient, a more stable and abundant form of nitrogen in the open ocean, is controlled primarily by assimilation by phytoplankton, regeneration through the decomposition of organic matter and denitrification under anaerobic conditions (WADA; HATTORI, 1991). Although nitrate is the most abundant form of nitrogen nutrient in the ocean, $\mathrm{N}$-ammonium is the form preferably assimilated by phytoplankton, since its ion has an optimal oxidation state for a more direct assimilation during the protein-forming process. Nitrite is the intermediate compound in the oxidation-reduction reactions between ammonium and nitrate. Nitrite is not found in high concentrations in the natural marine environment, and its concentration is governed mainly by biological processes such as oxidative production by nitrifying bacteria; the production and consumption through the respiration of bacteria that use nitrogen compounds 
as electron acceptors; and oxidative consumption by the nitrifying bacteria. Nitrogenous organic compounds can be found in the marine environment in particulate and dissolved forms in various chemical compounds (amino acids, proteins, lipid nitrogen, urea, alkaloids and others), with concentrations spatially and temporally distributed in different ways. Their decomposition can lead to the formation of ammonium and urea.

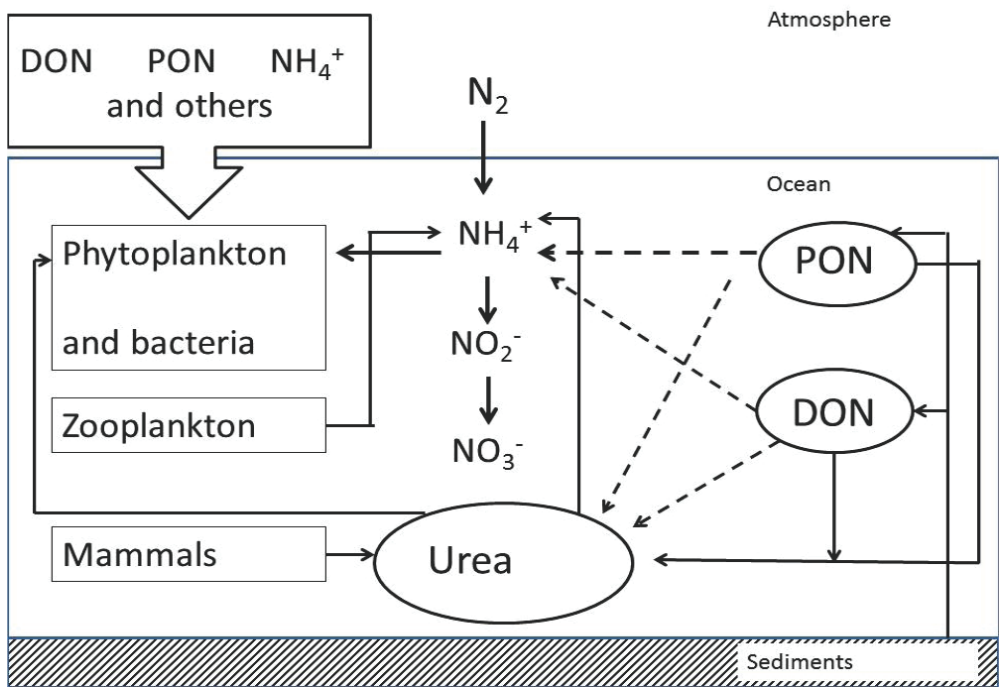

Figure 1. Simplified chart of the nitrogen cycle.

\section{UREA IN THE NITROGEN CYCLE}

The increase in urea concentrations in seawater is attributed to urban sewage and the contribution of atmospheric deposition is rare (COZZI et al., 2014). The main nitrogenous compounds excreted by marine organisms is belong to the amino acids group, but in mammals, urea is the predominant final metabolite. The concentration of urea in human urine in average is of $7.7 \mathrm{~g} \mathrm{~L}^{-1}$ (UDERT et al., 2006). At the same times, humans use urea in many industrial processes, and its determination in foods and beverages is important to evaluate the quality of these products and the efficiency of livestock feeding practices (FRANCIS et al. 2002) In the marine environment, urea is an important component of the biogeochemical cycle of nitrogen (ANTIA et al., 1991; BRONK, 2002; SOLOMON et al., 2010). Normally, low levels of urea are found in the open sea $(0.3 \mu \mathrm{mol} \mathrm{L}-1 \mathrm{~N})$, whereas higher values (reaching $13 \mu \mathrm{mol} \mathrm{L}-1 \mathrm{~N}$ ) are often observed in the coastal and estuarine zones.

Many marine organisms excrete various nitrogen products simultaneously, as is the case of some fish which eliminate ammonium, urea and creatine in different proportions (BRAGA, 2002). The presence of urea, despite not being the main product of the nitrogen excretion of many groups of organisms, is considered to be connected to two metabolic groups: the cycle of ornithine-urea on one hand and purine-urea, another part of the nitrogen cycle, on the other (BRAGA, 2002). A preference for the assimilation of urea by the diatom Phaeodactylum has been observed (MCCARTHY, 1972). In the biogeochemical nitrogen cycle, urea plays a role in the excretion of metabolic products of $\mathrm{N}$ and is also a source of dissolved organic nitrogen for some species and a substrate for bacteria.

\section{DISSOLVED ORGANIC PHOSPHORUS (DOP)}

Phosphorus is an essential nutrient for primary production and can be a limiting factor in marine systems (BENSON et al., 1996). In natural waters, dissolved phosphorus is found in several chemical forms that may be categorized as inorganic (protonated forms of $\mathrm{PO}_{4}^{3-}$ ) or organic (incorporated into organic molecules of biological origin, such as nucleic acids, polyphosphates, phosphorus esters and phosphonates) (THOMSON-BULLDIS; KARL 1998; BENITEZ-NELSON, 2000; KOLOWITH et al., 2001). It 
has always been generally accepted that all plankton can utilize inorganic phosphorus, however in the last 15 years, oceanographers have demonstrated that dissolved organic phosphorus (DOP) is available for production to both phytoplankton and bacteria (MONAGHAN; RUTTENBERG, 1999; KOLOWITH et al., 2001). Therefore, it is important to quantify organic phosphorus as it is potentially available for primary production in coastal systems.

\section{DISSOLVED ORGANIC CARBON (DOC)}

Many studies of the biogeochemistry of dissolved organic carbon (DOC) and dissolved organic nitrogen (DON) in the open oceans have been published in the last two decades (BATES; HANSELL, 1999; HANSELL, 2002). Despite the importance of marginal seas for the cycling of dissolved organic matter (DOM) (WALSH et al., 1988; WOLLAST, 1991), few studies have focused on these areas (HUNG et al., 2003).

The intense physical and biological processes which occur in coastal waters, make these part of the marine realm one of the most dynamic in terms of DOM (CAUWET, 2002). Globally, riverine inputs of DOM is about $0.25 \mathrm{Gt} C$ per year. This annual input accounts for only about $0.04 \%$ of the DOC content of the oceans, assessed at 685 Gt C (HANSELL; CARLSON, 1998).

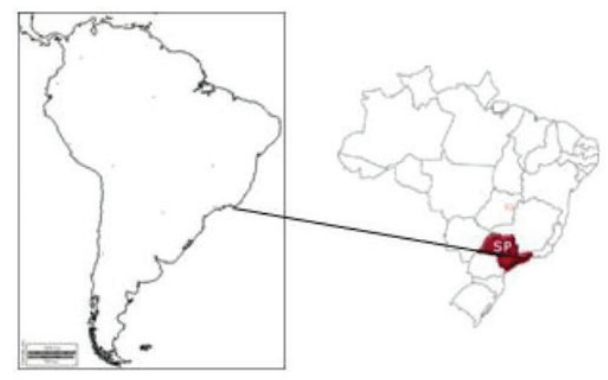

Despite its refractory character, a relatively large fraction of that DOM is degraded after being mixed with seawater, with turnover times ranging from days to years (CAUWET, 2002). Much remains to be learned about the spatial gradients of organic carbon and nitrogen and the processes that control the fluxes and cycling of carbon in ocean margins (BATES; HANSELL, 1999). Seasonal studies are important to understand the effect of wet and dry periods on the DOM cycling.

\section{STUDY AREA}

The Santos-São Vicente Estuarine System is located in the São Paulo coastal area of Brazil between latitudes $23^{\circ} 53^{\prime}$ and $24^{\circ} 01^{\prime} \mathrm{S}$ and longitudes $46^{\circ} 22^{\prime}$ and $46^{\circ} 19^{\prime} \mathrm{S}$ (Fig. 2). This region is considered to be an important economic region due to its harbor, industrial activity and tourism. The vegetation in the study area is characterized by an exuberant Atlantic forest and mangrove areas (BRAGA et al., 2000). The rainfall is heavy and can reach $2500 \mathrm{~mm} \mathrm{y}^{-1}$. From January to March the rainfall has been reported to reach $760 \mathrm{~mm}$ (DAEE, 2006). The population is of approximately 1,000,000 inhabitants, and this number almost doubles during the summer.

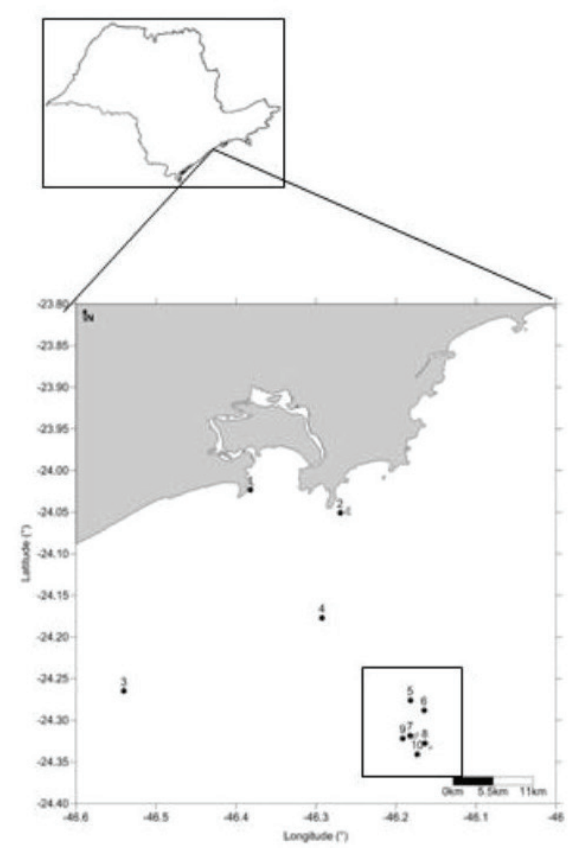

Figure 2. Localization of the sampling points in the continental shelf off São Paulo (Brazil) with the area of State Marine Park of Laje de Santos delimited by a little square. 


\section{MATERIAL AND METHODS}

\section{SEAWATER SAMPLING}

Seawater samples were collected in summer 2014 (January), winter 2014 (July) and summer 2015 (January), at 10 sampling stations in the Santos coastal region as far as the SMPLS (São Paulo - Brazil) (Fig. 2). The samples were collected using Hydrobios ${ }^{\circledR}$ bottles for the analyses of dissolved oxygen (DO) and $\mathrm{N}$-ammonium ( $\mathrm{N}$-ammon.). Van Dorn bottles were used for sampling dissolved inorganic phosphate (DIP) and, dissolved inorganic nitrogen (DIN; nitrate + nitrite + ammonium), dissolved organic carbon (DOC) and dissolved organic phosphate (DOP). The samples were obtained from $0 \mathrm{~m}, 5 \mathrm{~m}, 10 \mathrm{~m}, 20 \mathrm{~m}$ and $40 \mathrm{~m}$ depth.

After sampling, the water for chemical analysis were filtered in a preheated $\left(450^{\circ} \mathrm{C}\right.$ for $\left.4 \mathrm{~h}\right)$ Whatman ${ }^{\circledR} \mathrm{GF} / \mathrm{F}$ filter $(47 \mathrm{~mm})$. For DOC, a filtered subsample was acidified with $\mathrm{H}_{3} \mathrm{PO}_{4}$ in order to eliminate the carbonates (DIC).

\section{SEAWATER ANALYSES}

\section{PHYSICAL AND CHEMICAL PARAMETERS}

Temperature was measured with a protected reversing mercury thermometer. Salinity was determined using a Beckman ${ }^{\circledR}$ RS-10 induction salinometer. Dissolved Oxygen (DO) was measured according to the Winkler method (GRASSHOFF et al., 1983) using a Metrohm burette. Oxygen saturation (OS) was calculated by the equations of TRÉGUER; LE CORRE (1983). Oxygen saturation (OS) was calculated by AMINOT'S (1983) equation. Ammonium was measured by TRÉGUER; LE CORRE'S (1975) method. DIP was measured by the colorimetric method using the molybdenum blue reaction (GRASSHOFF et al., 1983).The urea content was determined using the analysis described by AMINOT; KEROUEL (1982). The analysis consists of adding $1 \mathrm{~mL}$ of the reagents A (diacetyl monoxide and thiosemicarbazide) and B (sulfuric acid and iron chloride) to $25 \mathrm{~mL}$ of the sample, storing it in a glass bottle and heating it in a water bath $\left(90^{\circ} \mathrm{C}\right)$ for 45 minutes. After this step, the samples were cooled for 5 minutes and analyzed in a spectrophotometer at $526 \mathrm{~nm}$. The method's detection limit was $0.01 \mu \mathrm{mol} \mathrm{L}^{-1}$ of N-urea, with linear response of up to 15 $\mu \mathrm{mol} \mathrm{L}{ }^{-1}$ of N-urea.

\section{Dissolved ORGANiC Nitrogen (DON) AND Dissolved Organic Phosphorus (DOP)}

Dissolved Organic Nitrogen (DON) and Dissolved Organic Phosphorus (DOP) were analysed by the
UV-oxidation process that determines Total Dissolved Nitrogen (TDN) and Total Dissolved Phosphorus (TDP) (ARMSTRONG et al., 1966). Dissolved nitrogenous compounds including organic forms are oxidized in seawater to nitrate in the presence of an excess of dissolved oxygen (addition of $\mathrm{H}_{2} \mathrm{O}_{2}$ ) under the action of the UV radiation energy. The extract after photo-oxidation was analysed by the nitrate and phosphate methods. For the DIN (Nitrate + Nitrite + N- ammonium) and phosphate determinations, see GRASSHOFF et al. 1983.

\section{Dissolved ORGANiC CARBON (DOC)}

DOC was determined by a high-temperature catalytic oxidation method using a Vario Cube (B) analyzer. Previously, the acidified seawater subsamples were purged with pure synthetic air for $5 \mathrm{~min}$. to eliminate inorganic carbon and then $7 \mathrm{~mL}$ of purged sample were directly injected into the vertical furnace, which contained a standard platinum catalyst at a temperature of $850^{\circ} \mathrm{C}$. The DOC oxidation was followed by non-dispersive infrared detection of the generated carbon dioxide. Only the blank of the instrument was considered as the DOC blank in the calculation of DOC concentrations. During the experiments, the instrument blank was about 3- $6 \mu \mathrm{mol} \mathrm{L}^{-1}$.

\section{DATA TREATMENT}

The Shapiro - Wink test was used to test the normality of the data and the seasonal variation between summer and winter was determined by the analysis of variance (ANOVA one way for $\mathrm{p}<0.01$ ) and Pearson correlation with significance level of 0.05 .

\section{RESULTS}

\section{PHYSICAL AND CHEMICAL CHARACTERISTICS}

Values of temperature, salinity, dissolved oxygen (DO), $\mathrm{pH}$, dissolved organic carbon (DOC), dissolved organic nitrogen (DON) and dissolved organic phosphorus (DOP) measured in the seawater samples are listed in table 1 . The temperature in the SMPLS region varied from 15.73 to $30.42^{\circ} \mathrm{C}$ in January 2014 , from 21.83 to $22.83^{\circ} \mathrm{C}$ in July 2014 and in January 2015 from 17.21 to $31.22^{\circ} \mathrm{C}$. The differences (ANOVA $\mathrm{p}<0.01$ ) between the water temperatures obtained in the three sampling periods (two summers and one winter) confirm the influence of South Atlantic Central Water (SACW) on the bottom of the water's column at the sampling stations in the summer periods (lowest values). 
Salinity varied from 32.92 to 35.97 , taking all the seasons sampled into consideration, and the highest and lowest salinity values were found in the winter of 2014. Dissolved oxygen varied from 3.60 to $6.86 \mathrm{~mL} \mathrm{~L}^{-1}$, with the highest values measured in July 2014 associated with a homogeneous water column and relatively low temperatures. No variations of $\mathrm{pH}$ values were record (Table 1, ANOVA $\mathrm{p}$ $<0.05$ ), with values between 8.20 to 8.49 , showing only an influence of continental waters in the most internal stations.

\section{Distribution OF DOC, DON AND DOP IN SUR- FACE WATERS}

DOC in surface water was significantly higher (ANOVA p <0.01) in January 2015, with an average of $103 \pm 71 \mu \mathrm{mol} \mathrm{L}{ }^{-1}$, compared with the samplings which occurred in January $2014\left(90 \pm 40 \mu \mathrm{mol} \mathrm{L}^{-1}\right)$ and in July $2014\left(72 \pm 29 \mu \mathrm{mol} \mathrm{L}^{-1}\right)$. DON also presented higher values in the summers of 2014 and 2015 (18.46 $\pm 3.18 \mu \mathrm{mol}$ $\left.\mathrm{L}^{-1}\right)$ and its lowest values in July $2014(7.26 \pm 1.16 \mu \mathrm{mol}$ $\mathrm{L}^{-1}$ ) in surface waters, probably a resulted from a different level of metabolism in these two periods in relation to organic primary production and excretion or the contribution of regeneration to major or minor inputs.

\section{MiXING DIAGRAMS}

The mixing diagram of DOC related to salinity considering all depths is given in figure 3. In January 2014 an irregular dispersion is observed. In July 2014, three regions of salinity are observed with similar concentrations of DOC of about 50-100 $\mu \mathrm{mol} \mathrm{L}^{-1}$. In other words, the concentration of DOC was constant for all salinity values. On the other hand, a typical mixing diagram is observed in January 2015, as the DOC decreased with salinity.

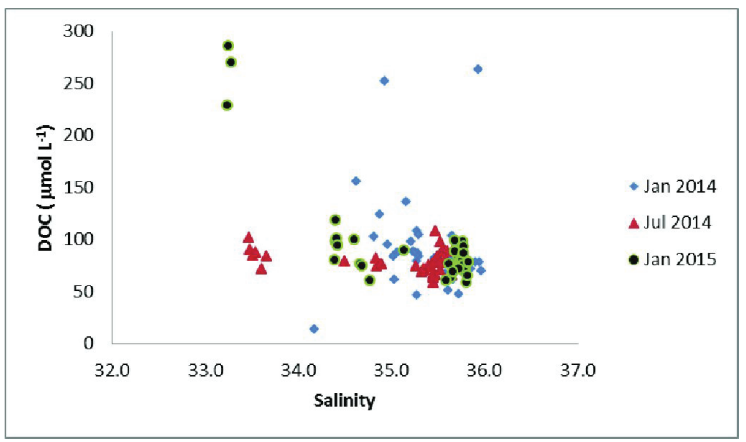

Figure 3. Mixing diagram of Dissolved Organic Carbon (DOC) in three sampling periods in the Santos coastal region.
The DON distribution exhibited a most evident dispersion with salinity (Fig. 4) in July 2014 and January 2015. The mixing was less effective in January 2014, however an important dilution was observed in some points with saltiest water.

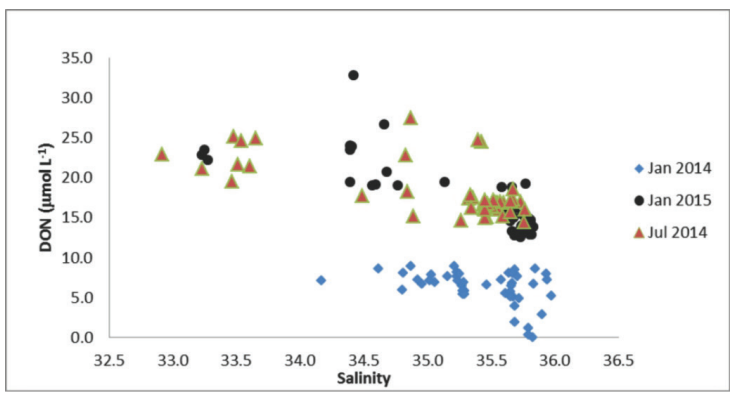

Figure 4. Mixing Diagram of Dissolved Organic Nitrogen (DON) in three sampling periods in the Santos coastal region.

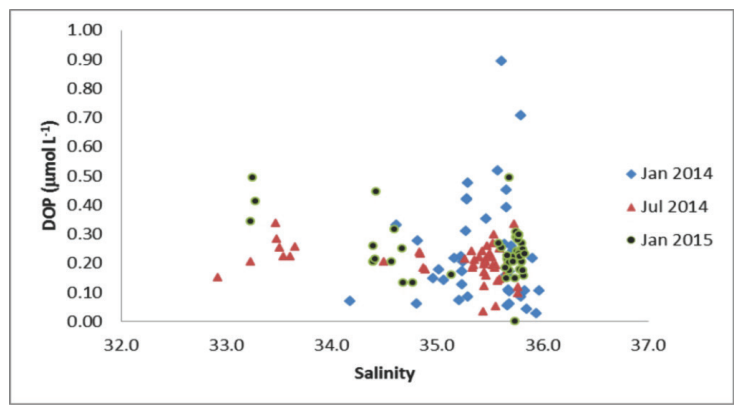

Figure 5. Mixing Diagram of Dissolved Organic Phosphate (DOP) in three sampling periods in the Santos coastal region.

The DOP values (Fig. 5) showed a spreading with salinity that revealed some relation in July 2014 and January 2015 and, as observed for DON, it was not possible to verify dispersion with salinity in January 2014.

In general, in the region studied (SMPLS and coastal areas) DOC, DON and DOP do not correlate with salinity (Figs 3, 4 and 5). Also, no correlation between organic nutrients and $\mathrm{pH}$ were found $(\mathrm{r}<0.30)$, indicating that processes other than mixing are involved in the variation of DON and DOP concentrations. In July 2014, DOC concentrations were practically constant (around $100 \mu \mathrm{mol}$ $\mathrm{L}^{-1}$ ), showing homogeneity of distribution in a period of maximum regeneration. The same case was observed by DAFNER et al (2007) in the Cape Fear River Estuary, where neither DON nor DOP correlates with salinity. 
Vertical PROFILES OF DOC, DON AND DOP DISTRIBUTIONS

Dissolved organic carbon varied from 14 to $263 \mu \mathrm{mol}$ $\mathrm{L}^{-1}$ in January 2014, 59 to $108 \mu \mathrm{mol} \mathrm{L}^{-1}$ in July and 59 to 286 $\mu \mathrm{mol} \mathrm{L}^{-1}$ in January 2015. The average ranged from $78 \pm 16$ mmol L-1 (July 2014) to $94 \pm 54 \mu \mathrm{mol} \mathrm{L}^{-1}$ (January 2015). The highest values of DOC were found in all depths of station 1 in January 2015. No difference in concentrations of DOC were observed in SMPLS (ANOVA $p<0.01$ ). In coastal waters (stations 1 to 4), high DOC concentrations were found in station 1 probably due to refractory organic matter from land. Lowest values were found in LSMSP stations, probably due to labile dissolved organic matter. Also, the highest values of DOC were observed at the depth of $25 \mathrm{~m}$ in two sampling: January and July 2014 (Fig. 6a and 6b). On the other hand, the concentrations of DOC in January 2015 (Fig. 5c) were homogeneous, between 80 and $100 \mu \mathrm{mol} \mathrm{L}^{-1}$.

No seasonal variations of DOC concentrations were observed during the three sampling seasons (ANOVA, $\mathrm{p}<$ $0.01)$. Still, it was possible to notice homogeneity of DOC concentrations in July 2014, with lower standard deviation compared to the other sampling seasons, a common characteristic of winter season.

Dissolved organic nitrogen ranged from 0.32 to 8.98 $\mu \mathrm{mol} \mathrm{L}{ }^{-1}$ in January $2014,14.42$ to $27.49 \mu \mathrm{mol} \mathrm{L}^{-1}$ in July and 7.00 to $12.60 \mu \mathrm{mol} \mathrm{L}^{-1}$ in January 2015. The average ranged from $6.46 \pm 1.96 \mu \mathrm{mol} \mathrm{L}^{-1}$ (January 2014) to $18.31 \pm 3.31$ $\mu \mathrm{mol} \mathrm{L} \mathrm{L}^{-1}$ (July 2014). Dissolved organic nitrogen (DON) presented the lowest values during the summer periods, considering the entire water column (Fig. $6 \mathrm{~d}$ and $6 \mathrm{f}$ ). Highest values were observed in July 2014 (winter) (Fig. 6e). The highest values were found at all stations and depths in winter sampling period. Total dissolved nitrogen (TDN), in general, varied from 7.02 to $33.41 \mu \mathrm{mol} \mathrm{L}^{-1}$ and the highest value of TDN was found at station 2 at a depth of $18 \mathrm{~m}$. Lower values of TDN were found in the SMPLS (stations 5 - 10).

Dissolved organic phosphorus varied from 0.03 to $0.89 \mu \mathrm{mol} \mathrm{L}^{-1}$ in January 2014, 0.03 to $0.34 \mu \mathrm{mol} \mathrm{L}^{-1}$ in July and 0.13 to $0.49 \mu \mathrm{mol} \mathrm{L}^{-1}$ in January 2015. The average ranged from $0.20 \pm 0.06 \mu \mathrm{mol} \mathrm{L}^{-1}$ to $0.25 \pm 0.09$ $\mu \mathrm{mol} \mathrm{L}{ }^{-1}$. The highest values of DOP were found in bottom waters in the summer sampling periods of 2014 and 2015 (Figs. $6 \mathrm{~g}$ and 6i) at the SMPLS stations (stations 9 and 10). Total dissolved phosphorus varied from 0.26 to $1.56 \mu \mathrm{mol}$ $\mathrm{L}^{-1}$, considering all seasons. The highest values of TDP were found at station 2 at the sea surface in January 2014.

Urea varied from 0.12 to $4.56 \mu \mathrm{mol} \mathrm{L}^{-1}$ with an average of $0.87 \pm 0.71 \mu \mathrm{mol} \mathrm{L}^{-1}$ in January 2014. In July 2014, values of urea ranged from 0.00 to $1.92 \mu \mathrm{mol} \mathrm{L}^{-1}$ with an average of $0.60 \pm 0.40 \mu \mathrm{mol} \mathrm{L}^{-1}$. Concentrations of urea in January 2015 varied from 0.00 to $1.30 \mu \mathrm{mol} \mathrm{L}^{-1}$ with an average of $0.25 \pm 0.26 \mu \mathrm{mol} \mathrm{L}^{-1}$.

Table 1. Physical and Chemical parameters of three campains of coastal and SMPLS.

\begin{tabular}{llll}
\hline & \multicolumn{1}{c}{ January 2014 } & \multicolumn{1}{c}{ July 2014 } & \multicolumn{1}{c}{ January 2015 } \\
\hline Temperature $\left({ }^{\circ} \mathrm{C}\right)$ & $14.73-30.42(23.86 \pm 6.65)$ & $21.30-25.50(21.69 \pm 0.35)$ & $17.21-31.22(27.00 \pm 4.37)$ \\
Salinity & $34.17-35.97(35.41 \pm 0.40)$ & $32.92-35.60(35.08 \pm 0.80)$ & $33.23-35.83(31.82 \pm 2.81)$ \\
Dissolved Oxygen $\mathrm{mL} \mathrm{L}^{-1}$ & $3.60-6.86(4.78 \pm 0.52)$ & $3.87-6.33(5.05 \pm 0.47)$ & $4.15-5.65(4.70 \pm 0.29)$ \\
DOC $\left(\mathrm{mg} \mathrm{L}^{-1}\right)$ & $0.56-3.16(1.11 \pm 0.52)$ & $0.70-1.29(0.94 \pm 0.13)$ & $0.70-3.43(1.13 \pm 0.59)$ \\
pH & $8.20-8.49(8.30 \pm 0.06)$ & $8.20-8.40(8.35 \pm 0.04)$ & $8.21-8.41(8.30 \pm 0.04)$ \\
DOC $\left.(\mu \mathrm{mol} \mathrm{L})^{-1}\right)$ & $14-263(90 \pm 45)$ & $59-108(78 \pm 10)$ & $58-286(94 \pm 50)$ \\
DON $\left(\mu \mathrm{mol} \mathrm{L}^{-1}\right)$ & $0.32-8.98(6.46 \pm 1.96)$ & $14.42-27.49(18.31 \pm 3.31)$ & $7.00-12.60(9.65 \pm 1.16)$ \\
DOP $\left(\mu \mathrm{mol} \mathrm{L}^{-1}\right)$ & $0.03-0.89(0.24 \pm 0.19)$ & $0.03-0.34(0.20 \pm 0.06)$ & $0.13-0.49(0.25 \pm 0,09)$ \\
TDN $(\mu \mathrm{mol} \mathrm{L}-1)$ & $7.02-15.95(9.92 \pm 1.81)$ & $15.33-32.66(19.19 \pm 3.76)$ & $13.50-33.41(17.93 \pm 4.43)$ \\
TDP $(\mu \mathrm{mol} \mathrm{L}-1)$ & $0.28-1.30(0.57 \pm 0.23)$ & $0.32-1.56(0.54 \pm 0.23)$ & $0.26-1.02(0.43 \pm 0.17)$ \\
Urea $(\mu \mathrm{mol} \mathrm{L}-1)$ & $0.74-4.81(2.66 \pm 0.94)$ & $0.05-1.92(0.62 \pm 0.40)$ & $0.00-1.25(0.20 \pm 0.24)$ \\
DOC:DON & $22-40(11 \pm 4)$ & $3-7(4 \pm 1)$ & $3-12(6 \pm 2)$ \\
DOC:DOP & $58-2884(640 \pm 46)$ & $254-2276(463 \pm 349)$ & $210-665(392 \pm 125)$ \\
O2 $:$ DOC & $0.74-4.81(2.66 \pm 0.94)$ & $2.12-3.91(2.92 \pm 0.43)$ & $0.77-4.14(2.53 \pm 1.02)$ \\
O2 :DON & $22-151(40 \pm 23)$ & $6-15(13 \pm 2)$ & $6-10(13 \pm 3)$ \\
O2 $:$ DOP & $204-7237(1825 \pm 1563)$ & $608-6800(1333 \pm 972)$ & $375-1592(941 \pm 339)$ \\
\hline
\end{tabular}




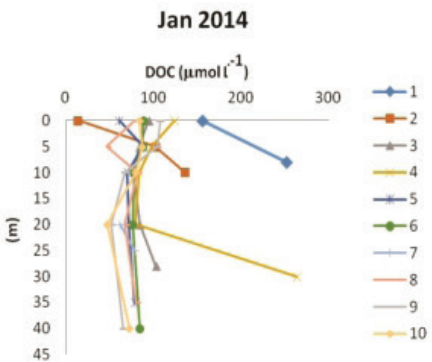

a

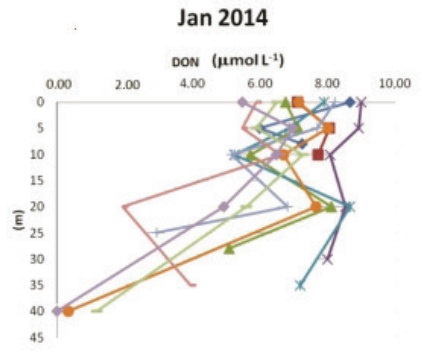

d

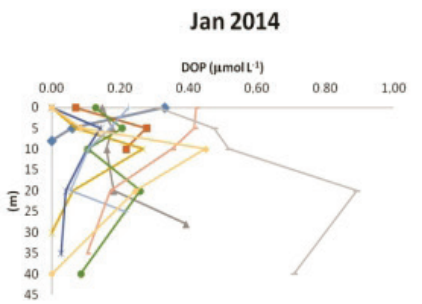

g

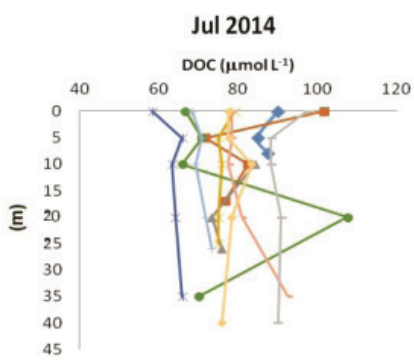

b

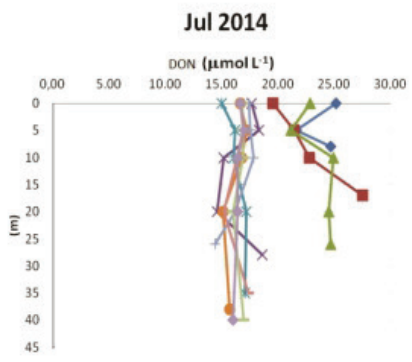

e

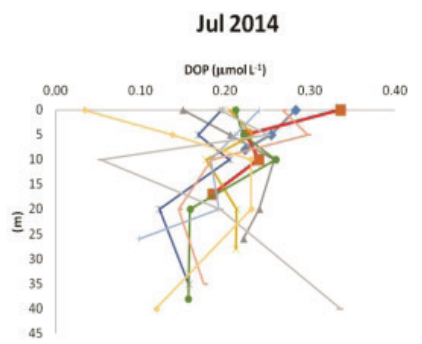

$\mathrm{h}$
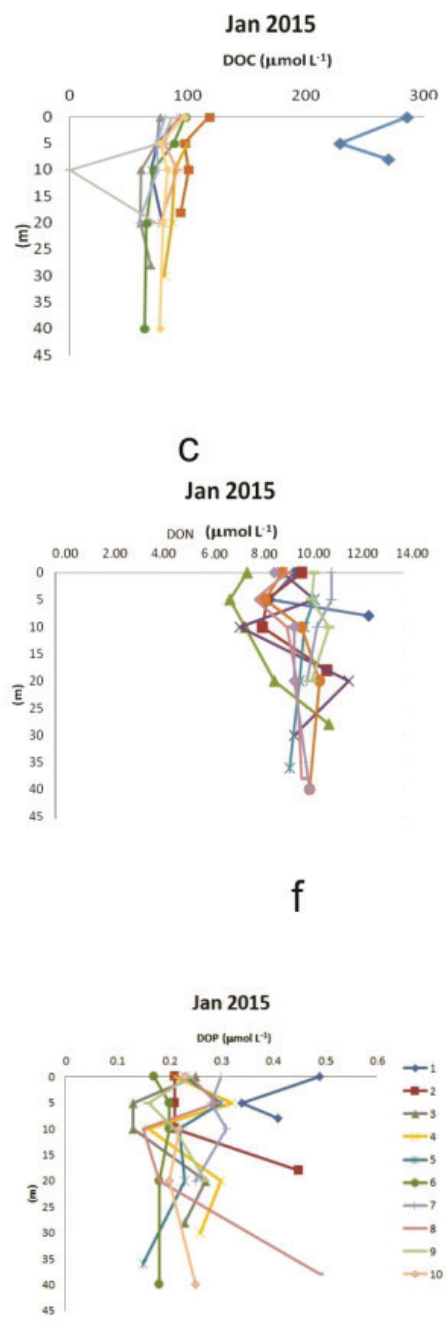

i

Figure 6. Vertical profiles of DOC (upper panels), DON (middle panels) and DOP (lowest panels) in three sampling periods: January 2014 (a, d and g), June 2014 (b, e and h) and January 2014 (c, f and i), in the Santos region, Brazil.

Observing the vertical distribution of the different parameters studied, it can note the irregular distribution with depth, but it is often very clear that the greatest concentrations are found in seasons 1 and 2, more coastal and less saline, observing the terrestrial contribution. In the most stations around the park, the variations in the vertical distribution showed more coherency with the influence of background relief in the hydrodynamics, being more complex the understanding of this distribution, but it occurs for many components, a general profile of lower concentrations of organic ones in the stations more far from the coast and the signs of biological productivity, in the shallower waters (euphotic layer) and summer (Fig. 6)

\section{DISCUSSION}

ORGANIC COMPOUNDS (DON, DOC AND DOP) THROUGHOUT THE COASTAL AREA WITH EMPHASIS ON THE SMPLS REGION.

Values of DOC, DON and DOP obtained in the continental shelf off Santos (coastal stations) and in the Sate 
Marine Park of Laje de Santos (SMPLS stations) and those obtained by other authors in coastal zones around the world are listed in table 2 for comparison purposes.

Box plot graphics of DOC, DON, DOP and urea concentrations measured in the SMPLS stations (panels at the left) and in all stations (panels at the right) are shown in Figure 7. The comparison between the SMPLS and total coastal stations is important to establish baseline values of dissolved organic compounds in the SMPLS, for DON, DOC and urea pools because values of DOM components in these areas are inexistent.

According to figure 7, DOC, DON and urea showed differences between the stations of the SMPLS (Figs 7b, $7 \mathrm{~d}$ and 7f) and the coastal stations (Figs 7a, 7c and 7e). DOC at the coastal stations reached $266 \mu \mathrm{mol} \mathrm{L}^{-1}$ (Fig. 7a), while at the SMPLS stations the maximum value was 100 $\mu \mathrm{mol} \mathrm{L}{ }^{-1}$ (Figs $7 \mathrm{~b}$ ). No seasonal variations were observed in DOC values (ANOVA $\mathrm{p}<0.01$ ).

On the other hand, DON presented spatial and seasonal differences, in the SMPLS the maximum value was 18 $\mu \mathrm{mol} \mathrm{L}{ }^{-1}$ (Figs $7 \mathrm{~d}$ ) and including the coastal stations, the value reached $27.49 \mu \mathrm{mol} \mathrm{L}^{-1}$ in July 2014 (Fig. 7c). DON represented 93-99\% of TDN (total dissolved nitrogen).

No spatial differences were observed (ANOVA $\mathrm{p}<$ $0.01)$ SMPLS and coastal stations, large variations of DOP values were observed in January 2014. However, DOP concentrations in July 2014 and Jaaury 2015 were similar for both regions In relation to DOP, the concentrations attained $0.90 \mu \mathrm{mol} \mathrm{L}^{-1}$ as the maximum value, considering all the surveys (Figs. 7e and 7f). These values were found in the stations 1 and presented seasonal variations with the highest values occuring in the summer. In the Santos Bay, other studies have reported maximum values of DOP of $1.00 \mu \mathrm{mol} \mathrm{L}^{-1}$ (BERBEL et al. 2008) and of $1.05 \mu \mathrm{mol} \mathrm{L}^{-1}$ in summer 2000 and $2.58 \mu \mathrm{mol} \mathrm{L}-1$ in winter 1999 (BRAGA, 2002). The trend to high concentrations of dissolved organic components in coastal zones and a decrease of ones on the continental shelf off Santos, where the SMPLS is located, are in agreement with the findings of Ribas-Ribas et al. (2011).

Lower percentages of DOP/TDP were found in coastal stations (1 to 4 ) that account for $5-49 \%$ in January 2014 , $20-49 \%$ in July 2014 and $30-66 \%$ in January 2015. On the other hand, percentages higher than $60 \%$ were found n SMPLS stations According to DAFNER et al. (2007), the predominance of DON and DOP in shelf waters and coastal could demonstrate an accumulation of these compounds as the result of terrestrial input from rivers as well of phytoplankton exudation. In this study, no large rivers or river runoff is located near the SMPLS, so the main predominance of DOP and DON in the this area may be attributed to phytoplankton exudation and/or to organic matter decomposition and excretion. 


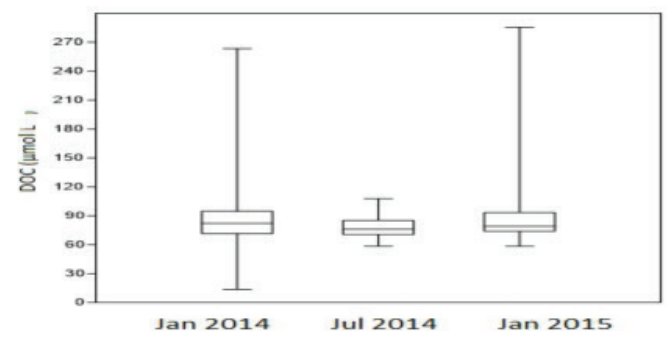

a

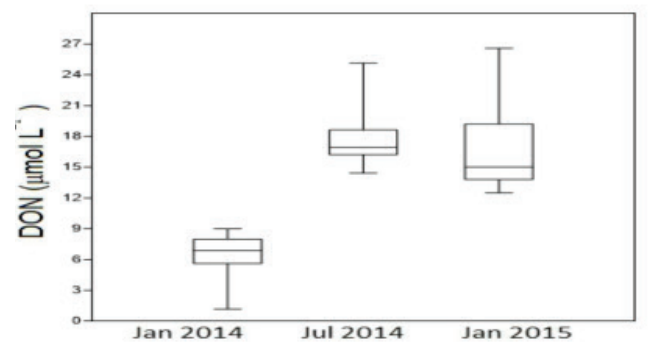

C

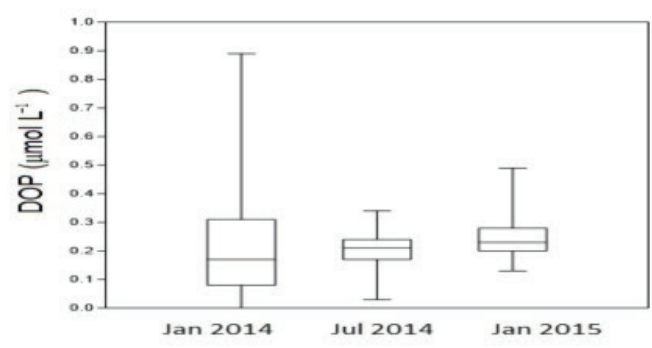

e

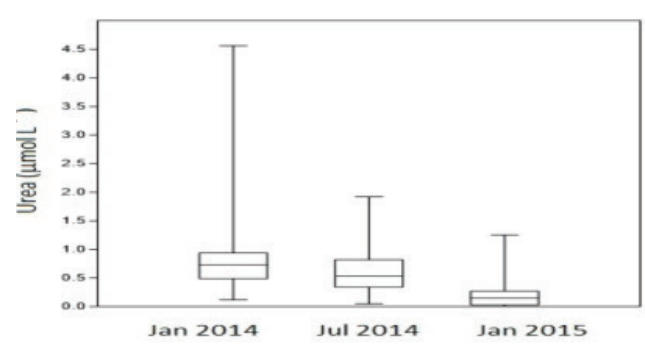

9
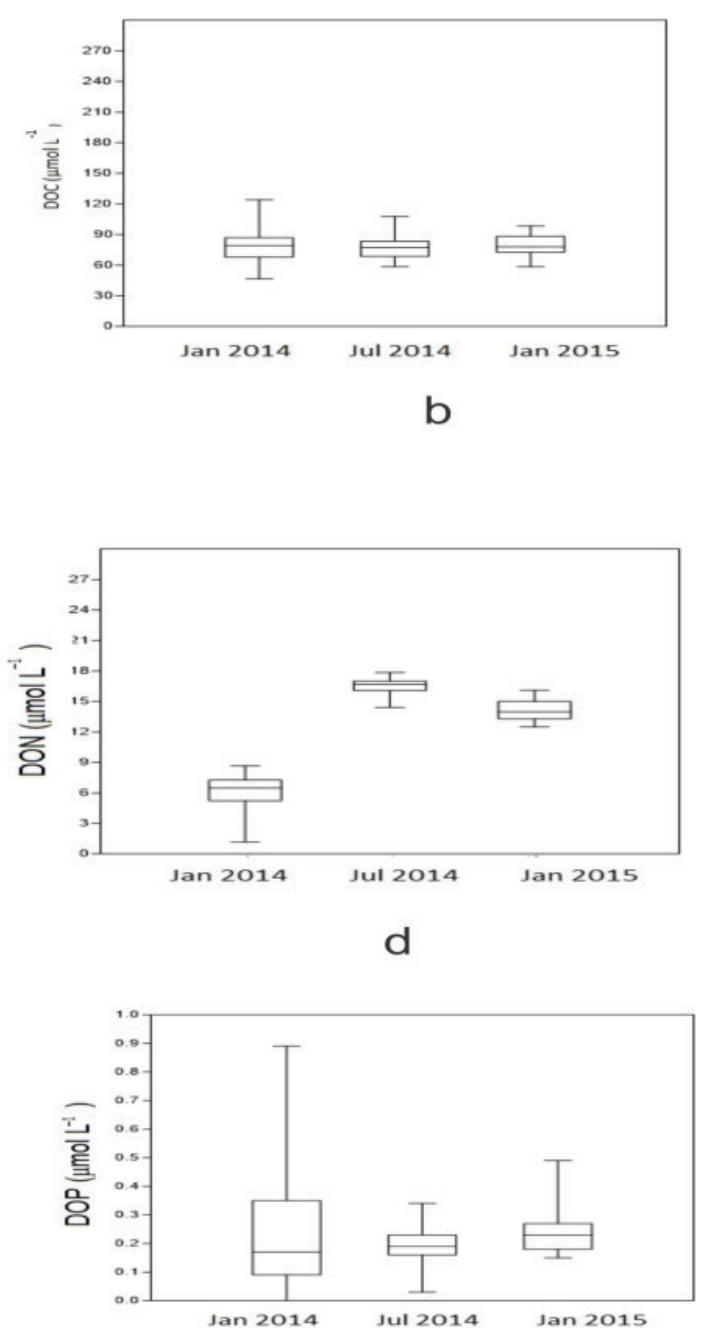

f

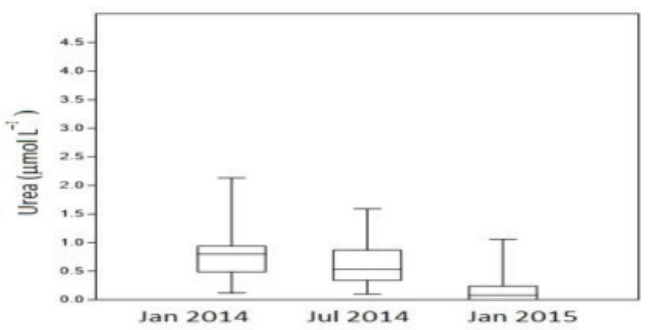

h

Figure 7. Box Plots of DOC at all stations (a) and SMPLS (b); DON at all stations (c) and LSMSP (d); DOP at all stations (e) and SMPLS (f); Urea at all stations (g) and SMPLS (h). 
Urea presented maximum concentration values in January 2014, of $2.0 \mu \mathrm{mol} \mathrm{L}{ }^{-1}$ (Fig. 7h) in the SMPLS and $4.5 \mu \mathrm{mol} \mathrm{L}^{-1}$ considering all stations (Fig. $7 \mathrm{~g}$ ). Lower concentrations of urea were observed in January 2015. COZZI et al. (2014) estimated background urea concentrations in the Gulf of Trieste of $1.2 \mu \mathrm{mol} \mathrm{L} \mathrm{L}^{-1}$, a similar finding to the average urea concentrations in the SMPLS (1.0 $\mu \mathrm{mol} \mathrm{L}^{-1}$ ) indicating low values as observed in marine unpolluted waters. BRAGA (1995) verified low values of urea in the Ubatuba region, around an island,

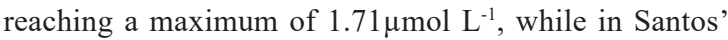
Bay, near human contribution by sewage, SARAIVA (2003) reported maximum value of $4.02 \mu \mathrm{mol} \mathrm{L}^{-1}$ in winter. Our results demonstrate that urea corresponds to 1 to $7 \%$ of total dissolved nitrogen and DON represents $83-$ $99 \%$ of total dissolved nitrogen indicating that proteins and aminoacids from marine and terrestrial sources are the main form of organic nitrogen.

Table 2. Values of DOP, DON, DOC and urea concentration (in $\mu \mathrm{mol} \mathrm{L}^{-1}$ ) in different regions around the world and in the present study.

\begin{tabular}{|c|c|c|c|c|c|}
\hline & $\begin{array}{c}\text { DOP } \\
\left.(\mu \mathrm{mol} \mathrm{L-})^{1}\right)\end{array}$ & $\begin{array}{c}\text { DON } \\
(\mu \mathrm{mol} \mathrm{L-1})\end{array}$ & $\begin{array}{c}\text { DOC } \\
\left.(\mu \mathrm{mol} \mathrm{L-})^{-1}\right)\end{array}$ & $\begin{array}{c}\text { Urea } \\
\left(\mu \mathrm{mol} \mathrm{L-}-^{-1}\right)\end{array}$ & References \\
\hline Bay of La Jolla & - & - & - & $0.54-1.00$ & McCarthy et al., 1972 \\
\hline Alaska coast & - & - & - & $0.25-2.20$ & De Manche, 1973 \\
\hline $\begin{array}{l}\text { Ubatuba } \\
\text { São Paulo-Brazil }\end{array}$ & - & - & - & $0.05-1.71$ & Braga,1995 \\
\hline Santos'Bay & $\begin{array}{l}0.11-0.76 \text { (winter) } \\
0.00-3.24 \text { (summer) }\end{array}$ & $\begin{array}{l}2.57-20.39 \\
1.49-25.07\end{array}$ & - & $\begin{array}{l}0.70-4.02 \\
0.40-3.60\end{array}$ & Saraiva, 2003 \\
\hline Mississipi Plume & $0.00-2.50$ & - & - & - & $\begin{array}{l}\text { Rinker \& Powell } \\
\text { (2002) }\end{array}$ \\
\hline $\begin{array}{l}\text { Cape Fear River (USA) } \\
\text { Estuary }\end{array}$ & $0.57-1.77$ & $14.80-37.79$ & - & - & Dafner et al. (2007) \\
\hline Santos Channel & $\begin{array}{l}0.00-2.08 \text { (summer) } \\
0.20-0.50 \text { (winter) }\end{array}$ & - & - & - & Berbel (2015) \\
\hline São Vicente Channel & $\begin{array}{l}0.50 \text { (summer) } \\
0.01-1.02 \text { (winter) }\end{array}$ & - & - & - & Berbel (2015) \\
\hline Plym Estuary (USA) & - & $10-80$ & $90-180$ & - & Badr et al. (2008) \\
\hline Gulf of Cadiz & - & $0-20$ & $42-198$ & - & $\begin{array}{l}\text { Ribas-Ribas et al. } \\
\text { (2011) }\end{array}$ \\
\hline $\begin{array}{l}\text { Gulf of Trieste } \\
\text { (Italy) }\end{array}$ & - & - & - & $1.2-20.0$ & Cozzi et al. (2014) \\
\hline Gulf of Riga (Baltic Sea) & - & - & $400-570$ & - & Hoikkala et al. (2015) \\
\hline Gulf of Finland & $0.06-0.29$ & $20.4-22.8$ & $483-690$ & - & Hoikkala et al. (2015) \\
\hline $\begin{array}{l}\text { SMPLS } \\
\text { São Paulo-Brazil }\end{array}$ & 0.03-0.89 & $0.92-32.76$ & $46-286$ & $0.12-4.56$ & This study \\
\hline
\end{tabular}

Dissolved organic compounds -molar ratios

The calculated mean (+ standard deviation) of the molar ratio of DOC:DON and DOC:DOP for each survey is presented in table 3 .

The highest mean values of DOC:DON molar ratios were found in January 2014 and varied from 8 to 27 . On the other hand, in January 2015 - as well as in July 2014 - the DOC:DON molar ratio decreased, varying from 3 to 12 and 3 to 7 , respectively. If a value closer to $6.6(\mathrm{C}: \mathrm{N}$ Redfield ratio) had been observed, that would indicate a major contribution of organic matter from plankton, fecal pellets and other compounds of biological origin, easily degradable (RIBAS-RIBAS et al., 2011).

In January 2014, the mean DOC:DON ratio of DOM throughout the study area was 3 to 6 times greater than the Redfield ratio. This may indicate the probable contribution of DOM derived from processed dissolved organic materials, but the low rainfall during January 2014 and warmer waters may encouraged the degradation processes of nitrogen compounds, reflected in the low values of DON in January 2014 as compared with January 
2015 and July 2014. One explanation of this fact could be that nitrogen-rich compounds (amino acids, proteins, etc.) are more labile than carbon-rich compounds (monoand polysaccharides, lipids, etc.in surface ocean waters (SAMBROTTO et al., 1993). Possibly the nitrogen component of algal DOM has been utilized; therefore in both July and February, the particulate organic matter had already been partly degraded.

Considering the SMPLS stations, the highest nitrate concentrations were found in January 2014 due to the occurrence of the SACW intrusion, hence, more labile
DON is produced due to primary production. On the other hand, lowest concentrations of nitrate were found in July 2014, with values typical of oligotrophic waters. The DOC:DON ratio near the Redfield ratio in July is probably due to a more refractory DON. In all the surveys, DON was the predominant fraction of TDN (total dissolved nitrogen). When no upwelling from SACW occurs, it is possible that DON was used as a source of nitrogen for primary producers, when no more nitrates were available.

Table 3. Values of dissolved organic $\mathrm{C}, \mathrm{N}$ and $\mathrm{P}$, total dissolved $\mathrm{N}$ and $\mathrm{P}$ and molar ratios of DOC and dissolves oxygen $\left(\mathrm{O}_{2}\right)$ with $\mathrm{N}$ and P, in January (summer) 2014, June 2014 (winter) and January (summer) 2015 (ranges, average and standard deviation).

\begin{tabular}{|c|c|c|c|}
\hline & JANUARY 2014 & JULY 2014 & JANUARY 2015 \\
\hline DOC $\left(\mathrm{mg} \mathrm{L}^{-1}\right)$ & $\begin{array}{c}0.56-3.16 \\
(1.11 \pm 0.52)\end{array}$ & $\begin{array}{c}0.70-1.29 \\
(0.94 \pm 0.13)\end{array}$ & $\begin{array}{c}0.70-3.43 \\
(1.13 \pm 0.59)\end{array}$ \\
\hline DOC $\left(\mu \mathrm{mol} \mathrm{L} \mathbf{L}^{-1}\right)$ & $\begin{array}{l}46-263 \\
(90 \pm 45)\end{array}$ & $\begin{array}{l}59-108 \\
(78 \pm 10)\end{array}$ & $\begin{array}{l}58-286 \\
(94 \pm 50)\end{array}$ \\
\hline DON $\left(\mu \mathrm{mol} \mathrm{L} \mathbf{L}^{-1}\right)$ & $\begin{array}{c}0.32-8.98 \\
(6.46 \pm 1.96)\end{array}$ & $\begin{array}{c}14.42-27.49 \\
(18.31 \pm 3.31)\end{array}$ & $\begin{array}{l}12.51-32.76 \\
(17.13 \pm 4.46)\end{array}$ \\
\hline DOP $\left(\mu \mathrm{mol} \mathrm{L}^{-1}\right)$ & $\begin{array}{c}0.03-0.89 \\
(0.24 \pm 0.19)\end{array}$ & $\begin{array}{c}0.03-0,34 \\
(0.20 \pm 0.06)\end{array}$ & $\begin{array}{c}0.13-0.49 \\
(0.25 \pm 0,09)\end{array}$ \\
\hline TDN $\left(\mu \mathrm{mol} \mathrm{L}^{-1}\right)$ & $\begin{array}{c}7.02-15.95 \\
(9.92 \pm 1.81)\end{array}$ & $\begin{array}{c}15.33-32.66 \\
(19.19 \pm 3.76)\end{array}$ & $\begin{array}{c}13.50-33.41 \\
(17.93 \pm 4.43)\end{array}$ \\
\hline TDP $\left(\mu \mathrm{mol} \mathrm{L}^{-1}\right)$ & $\begin{array}{c}0.28-1.30 \\
(0.57 \pm 0.23)\end{array}$ & $\begin{array}{c}0.32-1.56 \\
(0.54 \pm 0.23)\end{array}$ & $\begin{array}{c}0.26-1.02 \\
(0.43 \pm 0.17)\end{array}$ \\
\hline DOC:DON & $\begin{array}{l}22-40 \\
(11 \pm 4)\end{array}$ & $\begin{array}{c}3-7 \\
(4 \pm 1)\end{array}$ & $\begin{array}{l}3-12 \\
(6 \pm 2)\end{array}$ \\
\hline DOC:DOP & $\begin{array}{l}58-2884 \\
(640 \pm 46)\end{array}$ & $\begin{array}{c}254-2276 \\
(463 \pm 349)\end{array}$ & $\begin{array}{c}210-665 \\
(392 \pm 125)\end{array}$ \\
\hline $\mathrm{O}_{2}: \mathrm{DON}$ & $\begin{array}{c}22-151 \\
(40 \pm 23)\end{array}$ & $\begin{array}{c}6-15 \\
(13 \pm 2)\end{array}$ & $\begin{array}{c}6-10 \\
(13 \pm 3)\end{array}$ \\
\hline $\mathrm{O}_{2}: \mathrm{DOP}$ & $\begin{array}{c}204-7237 \\
(1825 \pm 1563)\end{array}$ & $\begin{array}{c}608-6800 \\
(1333 \pm 972)\end{array}$ & $\begin{array}{c}375-1592 \\
(941 \pm 339)\end{array}$ \\
\hline
\end{tabular}

DON $=$ Dissolved Organic Nitrogen DOP $=$ Dissolved Organic Phosphorus TDP $=$ Total Dissolved Phosphorus
DOC $=$ Dissolved Organic Carbon $\mathrm{TDN}=$ Total Dissolved Nitrogen $\mathrm{O}_{2}=$ oxygen gas
The molar ratio between dissolved oxygen, nitrate and o-phosphate in marine phytoplankton and in deep oceanic waters is almost constant $\left(\mathrm{O}_{2}: \mathrm{N}: \mathrm{P}=138: 16: 1\right.$; REDFIELD et al., 1963). DAFNER et al. (2007) found that values of $\mathrm{O}_{2}: \mathrm{DON}$ were close to the Redfield ratios in coastal waters (tidal creeks and estuary) and in shelf waters this ratio ranged from 24 to 49 . In the present study, the coastal environment (stations 1 to 4 ) presented the same behavior, i.e., the $\mathrm{O}_{2}: \mathrm{DON}$ values were close to the Redfield ratio, mainly at stations 2 and 3, both located near the $20 \mathrm{~m}$ isobath. As for the SMPLS stations (stations
5 to 10 ), the $\mathrm{O}_{2}$ :DON was extremely high in January 2014, especially at stations 8 (20 $\mathrm{m}$ depth) and 9 (40m depth), varying from 22 to 151 , while in the other seasons the values were between 6 and 15 . These high values of $\mathrm{O}_{2}: \mathrm{DON}$ indicate a deficit of organic nitrogen.

\section{CONCLUSION}

We studied the spatial and temporal variations of DOC, DON, DOP and urea in the coastal region and on the adjacent shelf (SMPLS) and demonstrated that in the 
marine park regionconcentrations of dissolved organic compounds were typical of continental shelves and regions with a low impact of anthropogenic pollution. During the winter survey, DON presented high concentrations in relation to the summers surveys evaluated. Urea represented $1-7 \%$ of total dissolved nitrogen (TDN), whereas DON ranged from $83-99 \%$ of TDN, implying that the major part of DON is derived from proteins and aminoacids from terrigenous and phytoplankton sources (DOC:DON molar ratio varied from 3 to 22). It was observed most remarkable DON role in this profile, once COD and POD normally are less refractory than nitrogen compounds, suffering dillution and decomposition by different ways. These data of DOC, DON and DOP forms arearare on this region and very important to establish baseline values of dissolved organic compounds, thus contributing to the management of this conservation unit.

\section{ACKNOWLEDGEMENTS}

The authors wish to thank Petrobrás (Petróleo Brasileiro) for their financial support and FUNDESPA (Fundação de Pesquisas Aquáticas) for the organization and management of the MAPEMLS project. We would also like to thank Chiara M. Vieira and Beatriz F. Scigliano for their collaboration with the organic phosphorus sampling and analyses , and Cassio Edelstein for his help with the sampling.

\section{REFERENCES}

ANTIA, N. J.; HARRISON, P. J.; OLIVEIRA, L. The role of dissolved organic nitrogen in phytoplankton nutrition, cell biology and ecology. Phycologia: v. 30, n. 1, pp. 1-89, 1991.

AMINOT, A. ; KEROUEL, R. Automatic-determination of urea in sea-water - A sensible method using diacetilmonoxime. Can. J. Fish. Aquat. Sci., v. 39 (1), p ; 174-183, 1982.

AMINOT, A.; CHAUSSEPIED, M. Manuel des analyses chimiques en milieu marin. 1 ère ed. Brest Cedex, Centre National pour 1' Exploitation des Océans (CNEXO), 1983. $395 \mathrm{p}$.

ARMSTRONG, F. A.; WILLIAMS, P. M. ; STRICKLAND, J. D. H. Photoxidation of organic matter in sea water by ultraviolet radiation, anlytical and application. Nature, v.211,p. 481-463, 1966.

BRONK, D. A. Dynamics of organic nitrogen. In: HANSELL DA, CARLSON CA (eds) Biogeochemistry of marine dissolved organic matter. Academic Press, San Diego, p 153-247, 2002.

BADR. E.A, TAPPIN; A. D., ACHTERBERG, E. P. Distributions and seasonal variability of dissolved organic nitrogen in two estuaries in SW England. Mar.Chem. v.110, p. 153-164, 2008.

BATES, N.R.; HANSELL, D. A. A high resolution study of surface layer hydrographic and biogeochemical properties between Chesapeake Bay and Bermuda. Mar. Chem. V. 67 (1-2) , p. 1-16, 1999.
BENITEZ-NELSON, C.R., 2000. The biogeochemical cycling of phosphorus in marine systems. Earth-Sci. Rev., v 51 (1-4), p. 109-135, 2000.

BENSON, R.L.; MCKELVIE, I.D., HART, B.T.; TROUNG, Y.B.; HAMILTON, I.C., Determination of total phosphorus in waters and wastewaters by on-line UV/thermal induced digestion and flowinjection analysis. Anal. Chim. Acta, v. 326, p. 29-39, 1996.

BERBEL, G.B.B., FAVARO, D. I. T., BRAGA, E. S. Impact of harbour, industry and sewage on the phosphorus geochemistry of a subtropical estuary in Brazil. Mar. Poll. Bull.,v. 93, p. 44-52, 2015.

BRAGA, E. S. Distribuição sazonal da uréia na região de Ubatuba $45^{\circ} 04 \mathrm{~W}$ e $23^{\circ} 04 \mathrm{~S}$. Publição Esp. Inst. Oceanogr. São Paulo, v. 11, p.91-98, 1995.

BRAGA, E. S. ; MÜLLER, t. j.Observation of regeneration of nitrate, phosphate and silicate during upwelling off Ubatuba, Brazil, 23ㅇ․ Cont. Shelf Res., v. 18, p. 915-927, 1998.

BRAGA, E. S. 1995. Nutrientes dissolvidos e produção primária do fitoplâncton em dois sistemas costeiros do Estado de São Paulo. Doctoral Thesis. Universidade de São Paulo . Departamento de Oceanografia Geológica. 2 vols.

BRAGA, E. S. 2002. Bioquímica Marinha e efeitos de poluição nos processos bioquímicos. $2^{\mathrm{a}}$ edição. São Paulo. FUNDESPA, 2001, 108p.

BRAGA, E. S.; BONETTI, C.V.D.H.; BURONE, L. ; BONETTIFILHO J. Eutrophication and bacterial pollution caused by industrial and domestic wastes at the Baixada Santista Estuarine System - Brazil. Mar. Poll. Bull, v. 40 (2), p. 165-173, 2000.

BRAGA, E. S.; FONSECA A. L. D. O. ; BOSQUILHA, G. E.; DUCATTI, G. M. ; AGUIAR, V. M. C. ; LIMA, C. A. C. ; ARASAKI, E. Eutrophication and bacterial pollution assessment risks on the Santos Bay's sandy beaches (Brazil):influence of seasonal conditions. J. Coast. Res., v. 35,p. 516-524, 2003.

BRONK, D. A. Dynamic of DON. In: HANSEL, D.A, ; CARLSON, C.A. (eds), Biogeochemistry of marine organic matter. Chapter 5.p 152-247. Academic Press.

CAUWET, G. DOM in the Coastal Zone. In: HANSELL, D.A., CARLSON, C.A. (Eds.), Biogeochemistry of Marine Dissolved Organic Matter. Academic Press, 2002, 774 p.

COZZI, S.; MISTARO, A.; SPARNOCCHIA, S.; COLUGNATI, L.; BAJT, O., TONIATTI, L. Anthropogenic loads and biogeochemical role of urea in the Gulf of Trieste. Sci. Total Environ., v. 493, p. 271-281, 2014.

DAEE, "Dados hidrográficos e pluviométricos dos anos de 19372004" consulted in: www.daee.sp gov.br. 2006.

DAFNER, E. V.; MALLIN , M. A., J. J.; WELLS, H. A. ;PARSONS, D. C. Nitrogen and phosphorus species in the coastal and shelf waters of Southeastern North Carolina, Mid-Atlantic U.S. coast. Mar. Chem., v. 103, p.89-303, 2007

DE MANCHE ; M. CURL, H. J. ; COUGHENOWER, D. D. An automated analysis for urea in seawater. Limnol. Oceanogr., v. 18(4), p. 686-893, 1973.

FRANCIS P.S.; LEWIS S.W.; LIM K.F. Analytical methodology for the determination of urea: current practice and future trends. Trends Analyt Chem., v. 21, p.389-400, 2002.

GRASSHOFF, K. Determination of oxygen. In. GRASSHOFF, K.; KREMLING, K.; EHRHARDT, M. Methods of Seawater Analysis. 2nd ed. Weinheim: Verlag Chemie, 1983, 419 p. 
HANSELL, D. A. DOC in the global ocean carbon cycle. In. HANSELL, D.A., Carlson, C.A. (Eds.), Biogeochemistry of Marine Dissolved Organic Matter. Academic Press, 2002, 774 p.

HANSELL, D.A.; CARLSON, C.A. Net community production of dissolved organic carbon. Global Biogeochem Cycles, v.12 (3), p. 443-453, 1998.

HOIKKALA L. ;KORTELAINENC, P. ; SOINNE, H.; KUO$\mathrm{SA}, \mathrm{H}$. Dissolved organic matter in the Baltic Sea. J. Marine Syst., v. 142, p. 47-61, 2015.

HUNG, J. J., CHEN; C. H., GONG, G. C.; SHEU, D. D.; SHIAH, F. K. Distributions, stoichiometric patterns and cross-shelf exports of dissolved organic matter in the East China Sea. Deep Sea Res. part 2, 50 (6-7): 1127-1145, 2003.

KOLOWITH, L. C.; INGALL, E. ; BENNER, R. Composition and cycling of marine organic phosphorus. Limnol. Oceanogr. , v. 46, p. $309-320,2001$.

MCCRTHY, J. J. Uptake of urea by natural population of marine phytoplankton. Limnol. Oceanogr., v. 17, p. 738-448, 1972.

MONAGHAN, E.; RUTTENBERG, K. C. Dissolved organic phosphorus in the coastal ocean: reassessment of available methods and seasonal phosphorus profiles from the Eel River shelf. Limnol. Oceanogr., v. 44, p. 1702-1714, 1999.

REDFIELD, A. C. Ketchum; B. H ; Richards, F. A.. The influence of organisms on the composition of the seawater. In: Hill, M.N. (Ed.), The Sea, v.2, Interscience Publishers, New York, 1963, 77p.

RIBAS-RIBAS, M.; GÓMEZ-PARRA A.; FORJA, J. M. Spatio-temporal variability of the dissolved organic carbon and nitrogen in a coastal area affected by river input: The northeastern shelf of the Gulf of Cádiz (SW Iberian Peninsula). Mar. Chem., v. 126, p. 295-308, 2011.

RINKER, K. R. ; POWELL, R. T. 2006. Dissolved organic phosphorus in the Mississipi River during spring and fall 2002. Mar. Chem., v.102, p. 170-179.

SOLOMON, C.M.; COLLIER.; J.L, BERG; G.M.; GLIBERT, P.M. Role of urea in microbial metabolism in aquatic systems: A biochemical and molecular review. Aquatic Microbial Ecol.y 59, 67-88, 2010.
SAMBROTTO, R. N.; SAVIDGE, G.; ROBINSON, C.; BOYD, P.; TAKAHASHI, T., KARL, D. M.ELEVATED consumption of carbon relative to nitrogen in the surface ocean. Nature, 14247-61, 1993.

SARAIVA, E. S. B. G. 2002. Nitrogênio e fósforo totais dissolvidos e suas frações inorgânicas e orgânicas: Considerações sobre a metodologia aplicada e estudo de caso em dois Sistemas Estuarinos do Estado de São Paulo. Livre-Docência Thesis. Instituto Oceanográfico. Universidade de São Paulo,133p.

THOMSON-BULLDIS, A.; KARL, D. Application of a novel method for phosphorus determinations in the oligotrophic North Pacific Ocean. Limnol. Oceanogr. V. 43 ; p.1565-1577, 1998.

TRÉGUER, P.; Le CORRE, P. Manuel d'analyses des sels nutritifs dasn l'eau de mer. 2ème éd. Brest. Université de Bretagne Occidentale, 1975, $110 \mathrm{p}$

UDERT, K. M. ; LARSEN, T. A; GUJER, W. Fate of major compounds in source-separated urine. Water Science and Technolgy, v.54 (11-12), p. 413-420, 2006.

VAN DE VOSSENBERG, J.; RATTRAY, J. E.; GEERTS, W.; KARTAL, B.; VAN NIFTRIK, L.; VAN DONSELAAR, E. G.; SINNINGHE DAMSTÉ, J. S.; STROUS, M. \& JETTEN, M. S. M., 2008. Enrichment ans characterization of marine anammox bacteria associated with global nitrogen as production. Environ. Microbiol., v. 10(11): p. 3120-3129, 2008.

WADA, E.; HATTORI, A. 1991. Nitrogen in the Sea: forms, abundances, and rate processes. CRC Press, Boca Raton, FL.

WALSH, J. J.; BISCAYE, P. E. ; CSANADY, G. T. The 19831984 shelf edge exchange processes (SEEP)-I experiment: hypotheses and highlights. Cont. Shelf Res., v.8, p. 435-456, 1988.

WOLLAST, R., 1991. The coastal organic carbon cycle: fluxes, sources, and sinks. In: MANTOURA, R.F.C.; MARTIN, J.M., WOLLAST, R. (Eds.), Ocean Margin Processes in Global Change. John Wiley and Sons Ltd, pp. 365-381. 